Article

\title{
Chlorides Entrapment Capability of Various In-Situ Grown NiAl-LDHs: Structural and Corrosion Resistance Properties
}

\author{
Muhammad Ahsan Iqbal ${ }^{1,2, *(\mathbb{C}) \text {, Luyi Sun }}{ }^{2}\left(\mathbb{0}\right.$, Humaira Asghar ${ }^{3}$ and Michele Fedel ${ }^{1, *(\mathbb{C}}$ \\ 1 Department of Industrial Engineering, University of Trento, via Sommarive 9, I-38123 Povo (TN), Italy \\ 2 Polymer Program, Institute of Materials Science and Department of Chemical and Biomolecular Engineering, \\ University of Connecticut, Storrs, CT 06269, USA; luyi.sun@uconn.edu \\ 3 US. Pakistan Center for Advanced Studies in Energy (USPCAS-E), National University of Science and \\ Technology (NUST), Islamabad 44000, Pakistan; asnhmara@gmail.com \\ * Correspondence: muhammadahsan.iqbal@unitn.it (M.A.I.); michele.fedel@unitn.it (M.F.); \\ Tel.: +39-320-0227519 (M.A.I.); +39-0461-285354 (M.F.);
}

Received: 16 January 2020; Accepted: 11 April 2020; Published: 14 April 2020

\begin{abstract}
In this work, various NiAl-LDH thin films, exhibiting specific surface morphologies, were developed directly on aluminum AA 6082 substrate to understand the two main characteristics of layered double hydroxide (LDH), i.e., ion-exchange behavior and barrier properties, which are found to have a significant influence on the LDH corrosion resistance properties. The as-prepared NiAl-LDH films were analyzed through the scanning electronic microscope (SEM), X-ray diffraction (XRD), while the corrosion behavior of the synthesized films was investigated by the electrochemical impedance spectroscopy (EIS) and potentiodynamic curves. The results indicated that NiAl-LDH microcrystals grow in various fashions, from porous relatively flat domains to well-developed platelet structure, with the variation of nickel nitrate to ammonium nitrate salts molar ratios. The LDH structure is observed in all cases and is found to cover the aluminum surface uniformly in the lamellar order. All the developed NiAl-LDHs are found to enhance the corrosion resistance of the aluminum substrate, specifically, a well-developed platelet structure is found to be more effective in chloride adsorptive and entrapment capabilities, which caused higher corrosion resistance compared to other developed NiAl-LDHs. The comparison of the synthesized NiAl-LDH morphologies on their ion-exchange capabilities, barrier effect and their combined effect on corrosion resistance properties is reported.
\end{abstract}

Keywords: NiAl-layered double hydroxide; surface morphologies; ion-exchange behavior; EIS; XRD; corrosion protection

\section{Introduction}

Protection against corrosion of aluminum alloys is a widely investigated subject to increase the usage of aluminum in a variety of applications due to aluminum high strength to weight ratio, thermal and electrical conductivities, along with their abundance and low price. In that scenario, numerous approaches have been studied to develop economic coating systems to protect aluminum alloys, for instance, magnetron sputtering [1], anodizing [2], self-assemble [3], polymeric coatings [4], and chemical conversion techniques [5]. Recently, layered double hydroxides (LDHs) have got prominent attention for potential applications in various fields, including, adsorbents [6], drug delivery systems [7], environmental sciences [8], and biomedical science [9]. LDHs have also be found an efficient system to enhance corrosion resistance due to their ion-exchange capabilities, high surface area, a wide range of cationic salts availability, cost-effectiveness and other lucrative characteristics [10-12]. LDH is 
a class of two-dimensional anionic clays, represented by the general formula $\left[\mathrm{M}^{2+}{ }_{1-x} \mathrm{M}^{3+}{ }_{x}(\mathrm{OH})_{2}\right]^{x+}$ $\left(\mathrm{A}^{\mathrm{n}-}\right)_{x / n}$, and exhibit a brucite like structure that formed when some of the divalent cations $\left(\mathrm{M}^{2+}\right)$ are substituted by trivalent cations $\left(\mathrm{M}^{3+}\right)$, while anions $\left(\mathrm{A}^{n}\right)$ stabilize the layered positive charge $[12,13]$. Generally, co-precipitated [14] and in situ growth methods are used to develop LDHs, while in situ growth approach can be an optimum choice due to strong adhesion with the substrate, caused by the chemical bonding between the two phases, and thus can prolong the service life of the LDH based anti-corrosion coatings, moreover simple synthetic approach also made it an attractive approach to investigate [10-13].

Numerous studies have been reported on the synthesis of various LDHs with different cationic source $\mathrm{Mg}^{2+}, \mathrm{Zn}^{2+}, \mathrm{Fe}^{2+}$, etc. on aluminum substrate and with various type of anions intercalated between the $\mathrm{LDH}$ interlayers. The $\mathrm{NO}_{3}{ }^{-}$has shown the lowest ion-exchange equilibrium constant among the following; $\mathrm{CO}_{3}{ }^{-}>\mathrm{SO}_{4}{ }^{-}>\mathrm{OH}^{-}>\mathrm{F}^{-}>\mathrm{Cl}^{-}>\mathrm{Br}^{-}>\mathrm{NO}_{3}$ [15], Therefore, it is easy choice for nitrate anions support to modify the $\mathrm{LDH}$ geometry by making ion-exchange with various corrosion inhibitors [16]. Recently, we succeeded to synthesize novel CaAl-LDH directly on an aluminum substrate and investigated their physical and electrochemical properties [11]. Nickel-based LDH can also be another class of LDH to enhance the metallic substrate corrosion resistance and to further ascribe various multifunctional properties in it. There are few reports on NiAl-LDH where $\mathrm{NiAl}-\mathrm{LDHs}$ are investigated for environmental and electrochemical applications [17-21]. Recently, $\mathrm{Ye}$, Xin, et al. synthesized NiAl-CO $\mathrm{CO}_{3}-\mathrm{LDH}$ on AZ31 magnesium alloy to enhance the alloy corrosion resistance [18], Zhang, Fazhi, et al. prepared NiAl-CO ${ }_{3}-\mathrm{LDH}$ on nickel foil and foams to analyze electrochemical properties [19], Liu, Yi, et al. synthesized $\mathrm{NiAl}-\mathrm{CO}_{3}-\mathrm{LDH}$ on pure aluminum and study the potentiodynamic studies but did not thoroughly investigate the corrosion resistance properties [20]. Carbonate intercalated LDHs may be ideal choice where carbonates ions are difficult to exchange with corrosive species thus cause an increase in corrosion inhibition capacity. However, it is advisable to synthesize nitrate-based LDHs, where nitrate groups act as active precursors to modify the LDH chemistry with different anticorrosion inhibitors through ion-exchange and can design multifunctional coating systems for corrosion protection. Furthermore, nitrate ions can exchange with the corrosive species and can hold them inside the interlayers [15].

Herein, we investigated the NiAl-NO $\mathrm{NO}_{3}$-LDHs films directly grown directly on aluminum AA6082 substrate, and the complete characterization of corrosion resistance properties is reported. Moreover, as the LDH anticorrosion properties mainly depends upon its barrier effect and of ion-exchange capabilities, in this work, we mainly focused on the understanding of influential impact of various NiAl-LDH morphological structures and measured their chloride uptake capabilities on contact with chloride electrolyte solution $(0.1 \mathrm{M} \mathrm{NaCl})$, to better analyze the chloride entrapment capabilities of synthesized NiAl-LDH. Further, the effort is made to analyze the comparative effect of ion-exchange and barrier properties of NiAl-LDHs on the corrosion resistance properties.

\section{Experimental Section}

\subsection{Material and Methods}

Aluminum AA6082 extruded ingot was purchased from Metal Center (Italy), containing (0.60-1.20) wt \% Mg, (0.10) wt \% Cu, (0.70-1.30) wt \% Si, (0.40-1.0) wt \% Mn, (0.50) wt \% Fe and balance Al. $\mathrm{Ni}\left(\mathrm{NO}_{3}\right)_{2} \cdot 6 \mathrm{H}_{2} \mathrm{O}$ (purity $\geq 98 \%$ ), $\mathrm{NH}_{4} \mathrm{NO}_{3}$ (purity $\geq 98 \%$ ), and $\mathrm{NaOH}$ were purchased from Merck $\mathrm{KGaA}$ (Darmstadt, Germany). The Al 6082 were cut to the size of $3.14 \mathrm{~cm}^{2}$ and were ground using $600 \#, 800 \#, 1200 \# 2400 \# 4000 \#$ grit silicon carbide papers, and were washed ultrasonically with ethanol for $10 \mathrm{~min}$, and further etched with $0.1 \mathrm{M} \mathrm{NaOH}$ solution for $1 \mathrm{~min}$ followed by rinsing in distilled water several times.

To synthesize NiAl-LDH, the four different solutions of $\mathrm{Ni}\left(\mathrm{NO}_{3}\right)_{2} 6 \mathrm{H}_{2} \mathrm{O}$ and ammonium nitrate salt were prepared, based on the variation of ammonium nitrate solution (Table 1), as the ammonium nitrate salt is found to be an effective reagent to obtain unique LDH morphological characteristics [12]. 
The $\mathrm{pH}$ of the prepared solutions was adjusted at 10 with a drop by drop addition of $0.3 \mathrm{~mol} / \mathrm{L} \mathrm{NaOH}$ solution. $70 \mathrm{~mL}$ of above-prepared solutions were purged with nitrogen gas for $30 \mathrm{~min}$ to remove adsorbed gases and were separately transferred into a $100 \mathrm{~mL}$ Teflon-lined autoclave. The pretreated aluminum substrates, which act as a source of $\mathrm{Al}^{3+}$, were placed in the above-prepared solutions and the system was treated in an oven at $130{ }^{\circ} \mathrm{C}$ for $24 \mathrm{~h}$. After experiment completion, the coated specimens were washed with deionized water and were dried with nitrogen gas.

Table 1. The molar concentration of salts for the formation of NiAl layered double hydroxides (LDH).

\begin{tabular}{ccc}
\hline Specimens & $\mathbf{N i N O}_{3} \mathbf{6} \mathbf{H}_{\mathbf{2}} \mathbf{O}$ & $\mathbf{N H}_{\mathbf{4}} \mathbf{N O}_{3}$ \\
\hline $\mathrm{NiAl}^{-} \mathrm{LDH}_{\mathrm{a}}$ & $0.003 \mathrm{M}$ & - \\
$\mathrm{NiAl}_{\mathrm{LDH}}$ & $0.003 \mathrm{M}$ & $0.003 \mathrm{M}$ \\
$\mathrm{NiAl}_{\mathrm{b} D H}$ & $0.003 \mathrm{M}$ & $0.009 \mathrm{M}$ \\
$\mathrm{NiAl}_{\mathrm{C}}$ & $0.003 \mathrm{M}$ & $0.018 \mathrm{M}$ \\
\hline
\end{tabular}

\subsection{Characterization}

The morphology of the synthesized NiAl-LDHs was characterized by SEM-EDX (JEOL JSM-IT300 equipped with an EDS detector, Tokio, Japan). The crystallographic structure was studied by XRD (XRD (X'Pert High Score diffractometer, Rigaku, Japan) was performed using cobalt K $\alpha$ emission, $\lambda=1.79 \AA^{-1}$ at $10 \mathrm{~mA}$ and $30 \mathrm{kV}$ conditions. The scanning rate was $4^{\circ} \mathrm{min}^{-1}$. The corrosion resistance of LDH was analyzed by the electrochemical measurements, performed in $0.1 \mathrm{M} \mathrm{NaCl}$ solution at ambient conditions using a Parstat 2273 potentiostat/FRA (Princeton Applied Research/Ametek, Berwyn, IL, USA). Fourier transformed infrared spectroscopy Varian 4100 FTIR Excalibur Series instrument (Agilent, Santa Clara, CA, USA), in the attenuated total reflectance (ATR) mode were recorded to analyze surface functional group and the chemical bonding of the samples, in the range of 550 to $4000 \mathrm{~cm}^{-1}$ with a $4 \mathrm{~cm}^{-1}$ resolution and at 32 scans, by using a diamond crystal as Internal Reflective element (IRE). A classic three-electrode cell configuration is used to measure the electrochemical properties of $\mathrm{NiAl}-\mathrm{LDH}$, in which a Pt plate served as the counter electrode, while Ag/AgCl (+207 mV vs. SHE) and prepared NiAl-LDH was used as the reference electrode and working electrode respectively. The prepared coatings were sealed by epoxy resin but leaving the testing surface $\left(3.14 \mathrm{~cm}^{2}\right)$ uncovered for the corrosion tests. The potentiodynamic measurements were performed at a scan rate of $2 \mathrm{mV} / \mathrm{s}$ versus OCP. EIS measurements were acquired from $100 \mathrm{kHz}$ down to $10 \mathrm{mHz}$, using a $5 \mathrm{mV}$ (rms) amplitude perturbation. Before the experimentation, the LDH film was exposed to the electrochemical solution $(0.1 \mathrm{M} \mathrm{NaCl})$ for 30 min for system stabilization.

\section{Results and Discussion}

\subsection{Structure and Morphology of the LDH Films}

Figure 1 shows the XRD patterns of the NiAl-LDHs, exhibits distinct reflection peaks around at $2(\theta) 11.7^{\circ}, 23.0^{\circ}, 35^{\circ}$ correspond to (003), (006) and (012) respectively, demonstrating the characteristics peaks of LDH formation [18,22]. The calculated cell parameters of the NiAl-LDHs are reported in Table 2. The "003" reflections of all synthesized NiAl-LDHs were observed almost on the same 2( $\theta)$ angle of $\sim 11.7^{\circ}$, indicating a basal spacing around $0.88 \mathrm{~nm}$, which correspond to the presence of $\mathrm{NO}_{3}$ inside LDHs $[23,24]$. With the variation of ammonium nitrate salt concentration, the intensity and broadness of the reflection peaks vary and diffraction peaks (003) of NiAl-LDH begin to be bit sharper, depicted the enhance crystallinity. Crystallite size reduced slightly from NiAl-LDH $\mathrm{L}_{\mathrm{a}}$ to NiAl-LDH $\mathrm{N}_{\mathrm{d}}$ where NiAl-LDH ${ }_{d}$ have shown crystallite size of $17.22 \mathrm{~nm}$, compare to $19.94 \mathrm{~nm}$ of NiAl-LDH $\mathrm{H}_{\mathrm{a}}$ The cell parameter " $\mathrm{c}$ " is further calculated by the correlation " $\mathrm{c}=3 \mathrm{~d}_{003}=6 \mathrm{~d}_{006}$ " where gradual reduction from NiAl-LDH $\mathrm{L}_{\mathrm{a}}$ to NiAl-LDH $\mathrm{d}_{\mathrm{d}}$ is observed. The basal spacing from NiAl-LDH $\mathrm{L}_{\mathrm{a}}$ to NiAl-LDH $\mathrm{N}_{\mathrm{d}}$ is found to reduce slightly, indicating the strong intercalation of $\mathrm{NO}_{3}{ }^{-}$ions. The interlayer thickness, lattice constants of " $c$ " and crystallite size for NiAl-LDHs are listed in Table 1. The selective samples, 
NiAl-LDH $\mathrm{L}_{\mathrm{d}}$, was further investigated by FTIR analysis in attenuated reflection mode as shown in Figure 2. The broadband displayed around $3370 \mathrm{~cm}^{-1}$ is assigned to $\mathrm{OH}$ group stretching, while absorption band around, 1627 to $1633 \mathrm{~cm}^{-1}$ caused due to the flexural oscillation peaks of interlayer water molecules [25]. Moreover, the absorption peaks around $1350 \mathrm{~cm}^{-1}$ assigned to the asymmetric stretching bond of intercalated $\mathrm{NO}_{3}{ }^{-1}$ [26]. The bond at 655,751 and $1202 \mathrm{~cm}^{-1}$ may associate with the Al-OH stretching [27].

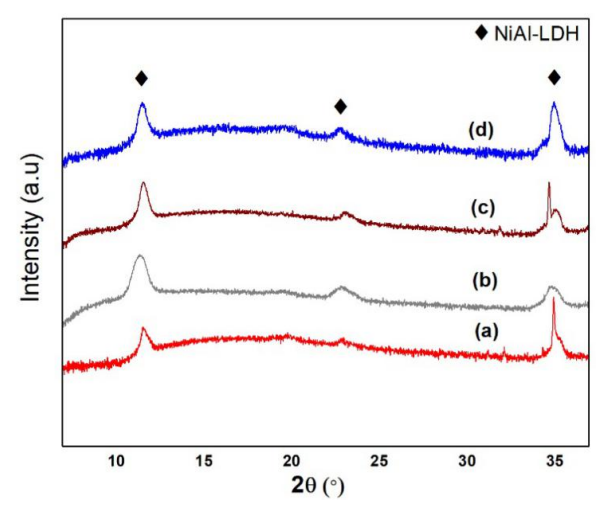

Figure 1. XRD patterns of the developed NiAl-LDH films, (a) $\mathrm{NiAl}-\mathrm{LDH}_{\mathrm{a}}$, (b) $\mathrm{NiAl}-\mathrm{LDH}_{\mathrm{b}}$, (c) NiAl$\mathrm{LDH}_{\mathrm{c}},(\mathbf{d}) \mathrm{NiAl}-\mathrm{LDH}_{\mathrm{d}}$.

Table 2. Calculated cell parameters of the NiAl-LDHs.

\begin{tabular}{|c|c|c|c|c|}
\hline Sample & $\begin{array}{l}\text { Interlayer Distance } \\
\text { "d } \mathrm{d}_{003} "(\mathrm{~nm})\end{array}$ & $\begin{array}{l}\text { Interlayer Distance } \\
\text { "d } \mathrm{d}_{006} "(\mathrm{~nm})\end{array}$ & $\begin{array}{l}\text { Cell Parameter, "c" } \\
(\mathrm{nm})\end{array}$ & $\begin{array}{l}\text { Crystallite Size } \\
003 \text { "nm" }\end{array}$ \\
\hline NiAl-LDH & 0.886 & 0.449 & 2.675 & 19.94 \\
\hline $\mathrm{NiAl-LDH} \mathrm{b}_{\mathrm{b}}$ & 0.881 & 0.449 & 2.668 & 18.72 \\
\hline $\mathrm{NiAl}-\mathrm{LDH}_{\mathrm{c}}$ & 0.878 & 0.448 & 2.659 & 17.64 \\
\hline NiAl-LDH ${ }_{d}$ & 0.872 & 0.449 & 2.656 & 17.22 \\
\hline
\end{tabular}

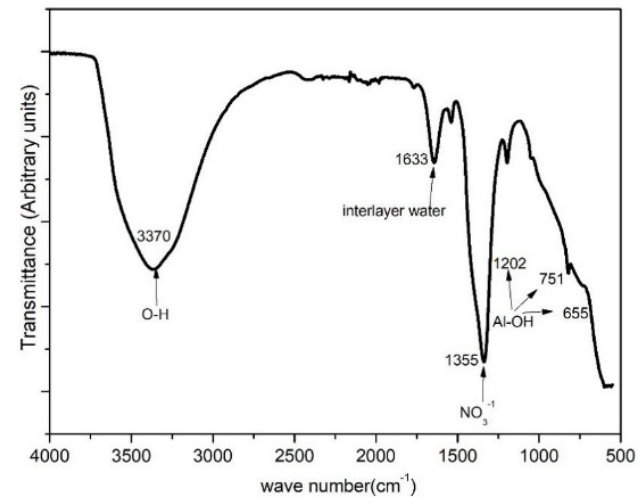

Figure 2. ATR-FTIR spectra of scraped NiAl-LDH $\mathrm{d}_{\mathrm{d}}$ powder.

Figure 3 shows the SEM images of the synthesized NiAl-LDHs, where in all cases, LDHs microcrystals uniformly covered the entire aluminum substrate surface in the lamellar form. By comparing the surface morphologies of obtained LDHs from NiAl-LDH ${ }_{a}$ to NiAl-LDH ${ }_{d}$, it can be found that NiAl-LDH ${ }_{a}$ is a less porous structure than that of $\mathrm{NiAl}-\mathrm{LDH}_{\mathrm{d}}$, where well ordered $\mathrm{LDH}$ platelet- structure is observed. This phenomenon is particularly evident in high-resolution SEM micrographs (Figure $3 b, d, f, h$ ), where four distinct morphologies can clearly be observed, from less porous amorphous structure to well-formed platelet flower-like structure. It can be concluded that due to well organize geometry structure, ion exchange property might be the basic attributes of NiAl- $\mathrm{LDH}_{\mathrm{d}}$ to increase the corrosion resistance of $\mathrm{Al}$ AA6082, while the comparatively NiAl- $\mathrm{LDH}_{\mathrm{a}}$ basically less profound to exchange $\mathrm{NO}_{3}{ }^{-}$with the $\mathrm{Cl}^{-}$and exposed to be more dominant barrier layer. The same trend is observed in the other developed 
NiAl-LDHs i.e., NiAl-LDH ${ }_{b}, \mathrm{NiAl}_{-} \mathrm{LDH}_{\mathrm{c}}$. Table 3 shown the weight \% composition of NiAl-LDHs, calculated by energy dispersive spectroscopy in-plane scanning mode. It is clear that NiAl-LDHs mainly consist of $\mathrm{Ni}, \mathrm{Al}, \mathrm{O}$, and $\mathrm{N}$. The $\mathrm{Ni} / \mathrm{Al}$ ratio from amorphous porous structure to platelet structure is found to be increased from 3.44 to 4 , which provides a reflection for the NiAl-LDH assembly. The effect of structural growth on the film thickness reported in Figure $4 b$, with a cross-sectional image of $\mathrm{NiAl}_{-} \mathrm{LDH}_{\mathrm{d}}$ in Figure $4 \mathrm{a}$ (reported as an example). It is clear that the film thickness remains in the range of 30 to $35 \mu \mathrm{m}$, and regular platelet $\mathrm{NiAl}-\mathrm{LDH}_{\mathrm{d}}$ structure has shown slightly higher film thickness $(34.6 \mu \mathrm{m})$ then amorphous $\mathrm{NiAl}-\mathrm{LDH}_{\mathrm{a}}$ structure $(30.01 \mu \mathrm{m})$. It can be said that the thickness of the LDH correlates with the amount of cations, $\mathrm{pH}$, reaction temperature, aging time, alkali solution and so on [28]. However, on consistent values of all the describe factors, that the morphological quality of LDH nanostructures increases with the increase of nitrate concentration in the solution. In an aqueous solution containing metallic aluminum and nitrate anions several electrochemical processes involving anodic dissolution of aluminum and cathodic reduction of nitrates and oxygen can occur. The cathodic processes generate hydroxyl ions and create a $\mathrm{pH}$ gradient. Although the reduction of nitrates to nitrite has been proven, there are other possible reactions involving nitrate and nitrite anions, producing nitrogen gas or ammonia, which may contribute to the overall reduction process [29] and thus can affect the film thickness as well surface morphology. In that view, we can say, the anions concentration in the solution may have effect on the growth rate of $\mathrm{LDH}$, but up to what extent, this is not clear.

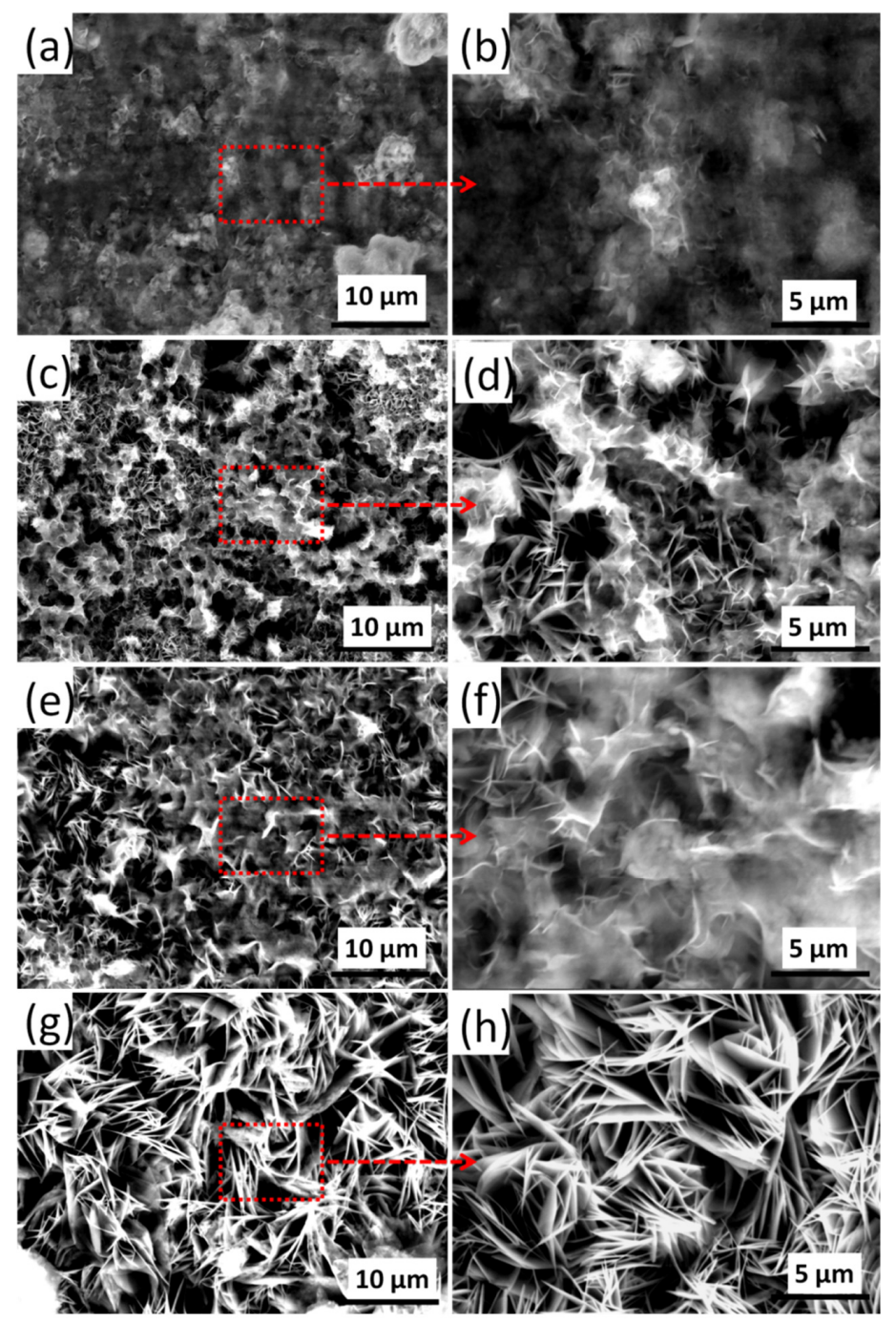

Figure 3. SEM images of the synthesized NiAl-LDH films: (a,b) NiAl-LDHa, (c,d) NiAl-LDH $(\mathbf{e}, \mathbf{f}) \mathrm{NiAl}-\mathrm{LDH}_{\mathrm{c}}$, and $(\mathbf{g}, \mathbf{h}) \mathrm{NiAl}-\mathrm{LDH}_{\mathrm{d}}$. 
Table 3. EDS quantitative analysis of the synthesized NiAl-LDHs.

\begin{tabular}{cccccc}
\hline \multicolumn{7}{c}{ The Weight Percentage of NiAl-LDHs } \\
\hline Sample & Ni & Al & N & O & Ni/Al \\
\hline NiAl-LDH $_{\mathrm{a}}$ & $26.2 \pm 2.2$ & $7.60 \pm 4.1$ & $4.1 \pm 1.3$ & $56.7 \pm 5.2$ & 3.44 \\
NiAl-LDH $_{b}$ & $26.4 \pm 2.5$ & $7.51 \pm 4.3$ & $4.8 \pm 1.7$ & $57.2 \pm 5.3$ & 3.51 \\
NiAl-LDH $_{\mathrm{C}}$ & $31.8 \pm 3.1$ & $7.48 \pm 4.2$ & $4.3 \pm 1.2$ & $52.7 \pm 5.1$ & 4.25 \\
NiAl-LDH $_{\mathrm{d}}$ & $34.7 \pm 3.8$ & $7.42 \pm 4.7$ & $4.6 \pm 1.4$ & $53.0 \pm 5.6$ & 4.67 \\
\hline \multicolumn{7}{c}{ The Atomic Percentage of NiAl-LDHs } \\
\hline Sample & $\mathbf{N i}$ & Al & N & O & Ni/Al \\
\hline NiAl-LDH $_{\mathrm{a}}$ & $9.7 \pm 3.2$ & $6.7 \pm 2.1$ & $5.6 \pm 1.1$ & $68.5 \pm 4.2$ & 1.44 \\
NiAl-LDH $_{\mathrm{b}}$ & $10.1 \pm 3.5$ & $6.4 \pm 2.2$ & $5.3 \pm 1.8$ & $69.2 \pm 4.3$ & 1.57 \\
NiAl-LDH $_{\mathrm{c}}$ & $10.4 \pm 2.9$ & $6.0 \pm 3.3$ & $5.1 \pm 1.9$ & $70.7 \pm 4.4$ & 1.73 \\
NiAl-LDH $_{\mathrm{d}}$ & $10.8 \pm 2.1$ & $5.9 \pm 3.7$ & $5.2 \pm 1.4$ & $69.0 \pm 5.5$ & 1.83 \\
\hline
\end{tabular}
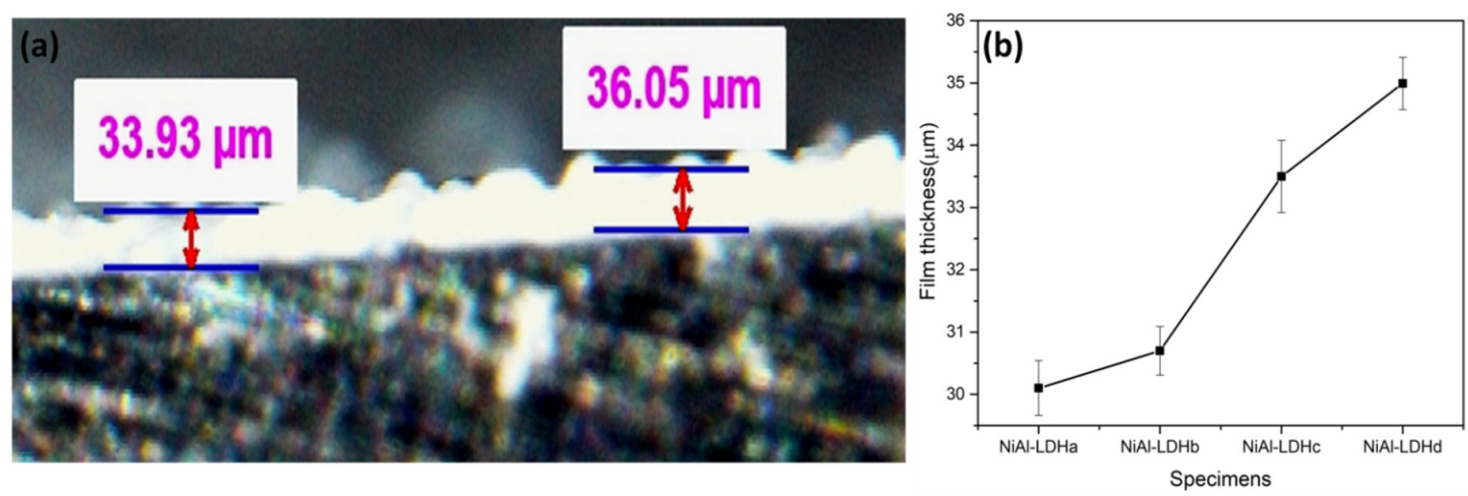

Figure 4. (a) For representation, the optical images of NiAl-LDH $\mathrm{L}_{\mathrm{d}}(\mathbf{b})$ thickness of the NiAl-LDH films measured from the cross-sectional optical microscope images.

The possible formation mechanism of NiAl-LDH is associated, where the aluminum surface dissolved in the basic reaction solution to form $\mathrm{Al}^{3+}$. The anodic regions results in the large concentrations of $\mathrm{OH}^{-}$groups on the surface of aluminum and favor the formation of $\mathrm{Al}(\mathrm{OH})_{3}$ which act as a precursors for the formation of $\mathrm{LDH}$, while the final step is related to the precipitation of $\mathrm{Ni}$, $\mathrm{OH}$ and $\mathrm{NO}_{3}$ on the surface of $\mathrm{Al}(\mathrm{OH})_{3}$ to form the NiAl-LDH hydroxide mixture. Finally, the divalent $\mathrm{Ni}^{2+}$ ions in $\mathrm{Ni}(\mathrm{OH})_{2}$ were substituted by the trivalent $\mathrm{Al}^{3+}$ ions, which result in the coexistence of $\mathrm{Al}(\mathrm{OH})_{3}$ and $\mathrm{Ni}(\mathrm{OH})_{2}$ to form precursor film of hydrotalcite-like LDH structure [30-32].

\subsection{Corrosion Behavior of the LDH Films}

The polarization curves of the developed NiAl-LDH on AA6082 are shown in Figure 5. The polarization curves of synthesized NiAl-LDHs coating have shown a decrease in both anodic and cathodic current density compared to the bare AA6082. All the synthesized NiAl-LDHs films on AA6082 have shown lower corrosion current density along with a shift of the corrosion potential to higher values as compared to bare AA6082, however, NiAl- $\mathrm{LDH}_{\mathrm{d}}$ has shown the significantly reduced anodic and cathodic current density compared to the substrate and also from other developed NiAl-LDHs. It is also worthy to note that NiAl- $\mathrm{LDH}_{d}$ has shown the relatively higher film thickness of around $35 \mu \mathrm{m}$, which may provide a comparatively better barrier film against the aggressive media, and this phenomenon is well correlated with the previous works [10-13] and for NiAl- $\mathrm{LDH}_{d}$ a reduction of about 3-orders of magnitude in corrosion current density was observed compared to the substrate. Furthermore, the open circuit potential (OCP) is switched toward nobler values with structural variation from $\mathrm{NiAl}-\mathrm{LDH}_{\mathrm{a}}$ to $\mathrm{NiAl}-\mathrm{LDH}_{\mathrm{d}}$, whilst a high corrosion potential of $-0.18 \mathrm{~V} \mathrm{vs}$. $\mathrm{Ag} / \mathrm{AgCl}$ was observed for NiAl- $\mathrm{LDH}_{\mathrm{d}}$, probably due to the formation of well-ordered platelet structure. 


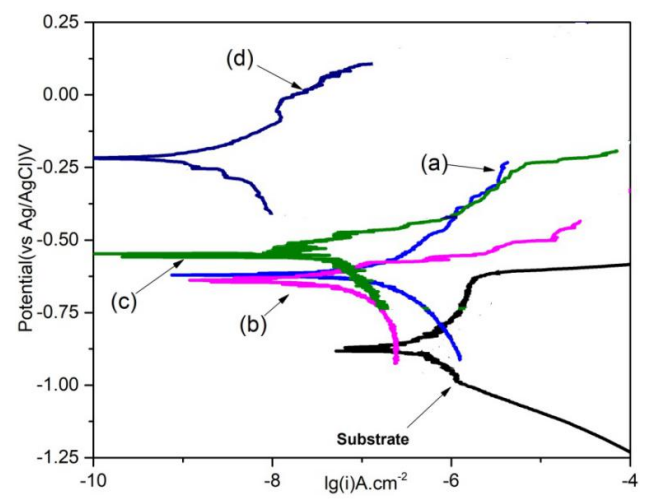

Figure 5. Polarization curves in $0.1 \mathrm{M} \mathrm{NaCl}$ aqueous solution: (a) $\mathrm{NiAl}-\mathrm{LDH}_{\mathrm{a}}$, (b) $\mathrm{NiAl}-\mathrm{LDH}_{\mathrm{b}}$, (c) $\mathrm{NiAl}-\mathrm{LDH}_{\mathrm{c}}$, and (d) NiAl-LDH .

The EIS measurements of as-prepared NiAl-LDHs after1 day immersion in $0.1 \mathrm{M} \mathrm{NaCl}$ solution are shown in Figure 6. The higher value of impedance in the low-frequency domain (impedance modulus at $\left.0.01 \mathrm{~Hz},|\mathrm{Z}|_{0.01}\right)$ roughly indicates higher corrosion resistance properties [33]. From Figure 6a, $\mathrm{NiAl}^{-\mathrm{LDH}_{\mathrm{d}}}$ has shown the impedance value around $6.3 \Omega \mathrm{cm}^{2}$ at $|Z|_{0.01}$, which is near 2-orders magnitude higher than bare AA6082 alloy. The higher shift of impedance for NiAl-LDH $\mathrm{C}_{\mathrm{c}}$ and NiAl-LDH $\mathrm{L}_{\mathrm{d}}$ defined the presence of the strong dielectric protective film which is well consistent with the anti-corrosion behavior obtained from the potentiodynamic curves and also it well explained the ion-exchange effect on the increase in corrosion resistance. In fact, the LDHs are related to providing corrosion protection due to: (1) barrier effect, as they are dielectric materials which protect the metal surface by avoiding the interaction with the metal substrate; and (2) by ion-exchange capability and entrapping $\mathrm{Cl}^{-}$ions by releasing nitrates [34].
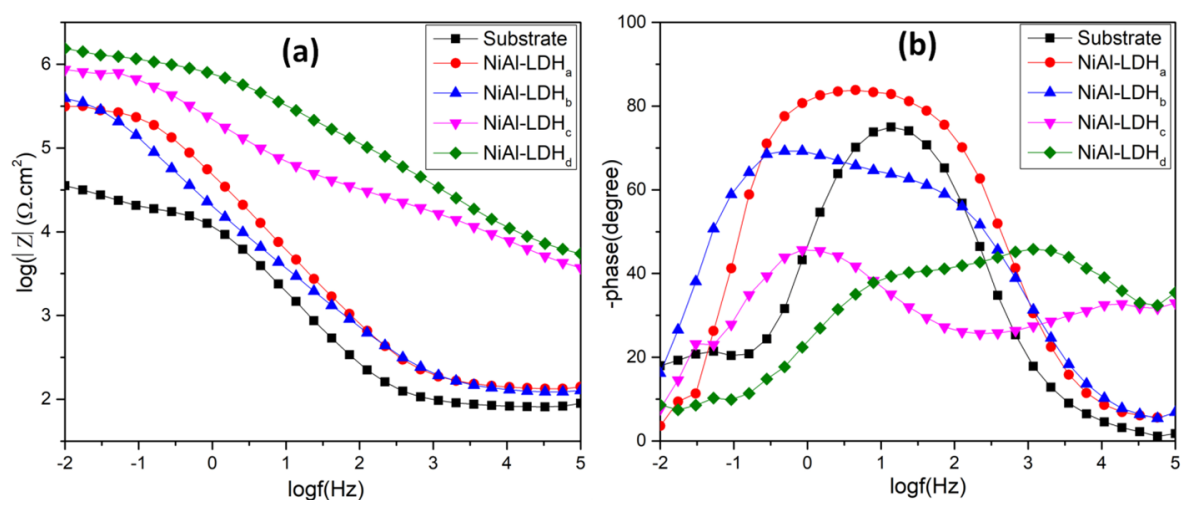

Figure 6. Impedance modulus (a) and phase (b) plots of NiAl-LDH coated specimens at various synthetic conditions in $0.1 \mathrm{M} \mathrm{NaCl}$ solution after 1-day immersion.

Considering the EIS response of the samples, two relaxation processes can be observed in the phase angle spectrum (Figure $6 \mathrm{~b}$ ): The time constant in the high-frequency range $\left(10^{3}-10^{4} \mathrm{~Hz}\right)$ can be attributed to the properties of the LDH layer itself, while the time constants in the middle frequency range $10^{0}-10^{1} \mathrm{~Hz}$ are the overlapping of the contributions of the aluminum oxide and of the faradic process of substrate and solution interphase. In the case of aluminum AA6082 substrate, two-time constants can also be observed, one related to the formation of the oxide in the middle-frequency range and other due to corrosion reactions in the low-frequency range. The EIS results (Table 4) were further fitted using "ZSimpWin" software to get more detail of corrosion resistance properties in an effort to understand in detail the effect of surface morphologies on the corrosion resistance parameters. As the synthesized coating has shown two relaxation processes from middle-high to low-middle frequency range due to coating systems, while the variation in LDH film thickness can also be responsible for the change in behavior of electrochemical response and so as defects/porosity. 
The electrical equivalent circuit $R_{\mathrm{S}}\left(C P E_{\mathrm{LDH}}\left(R_{\mathrm{LDH}}\left(C P E_{\mathrm{dl}} R_{\mathrm{ct}}\right)\right)\right)$ is used to analyze the EIS response of NiAl-LDHs, [35,36], where $R_{\mathrm{S}}$ is the resistance of electrolyte, while $R_{\mathrm{LDH}}$ describe the NiAl-LDH film resistance with a constant phase element which accounts for the Dielectric properties of the LDH film $\left(C P E_{\mathrm{LDH}}\right)$ and $R_{\mathrm{ct}}$ represents the charge transfer resistance in parallel with constant phase element $\left(C P E_{\mathrm{dl}}\right)$. According to the mathematical representation of a $C P E$, (i.e., $Z_{\mathrm{CPE}}=1 /\left(Q(\omega j)^{\alpha}\right)$ the parameters $\mathrm{Q}$ and $\alpha$ have been employed to describe the response of the electrodes. The total resistance $\left(R_{\mathrm{t}}\right)$ can be used to analyze the protective ability of deposited NiAl-LDHs. Since the $R_{\mathrm{t}}$ values give relative information related to the corrosion rate i.e., higher is the total resistance, lower will be the corrosion rate. It can be seen that total resistance $\left(R_{\mathrm{t}}=R_{\mathrm{ct}}+R_{\mathrm{LDH}}\right)$ gradually increases with the change of surface morphologies (porous domains to platelet structure), moreover, a well-formed platelet structure showed the higher value of total resistance. The relatively high values of $R_{\mathrm{LDH}}$ values indicate that the LDH coatings are more compact while also protective as suggested by the relatively high values of $R_{\text {ct }}$. This is well consistent with the polarization curves and bode plots analysis, but here it is also important to mention that $C P E_{\mathrm{LDH}}$ and $C P E_{\mathrm{dl}}$ have a value of $\alpha$ far from 1, and thus the film did not act as a pure capacitance and it is difficult to interpret the real physical meanings of EIS fitting parameters. From electrochemical and physical characterization, we can conclude that better is the ion-exchange capability to hold firmly the chlorides inside the interlayer's, the better is the corrosion resistance properties. The equivalent circuit used to model the impedance results is shown in Figure 7 , along with an example of fitting the experimental results of NiAl- $\mathrm{LDH}_{\mathrm{d}}$. The well organizes geometry of NiAl-LDH is found to facilitate better ion-exchange with the $\mathrm{Cl}^{-}$and strongly hold them between the LDH interlayer's thus act as a strong protective film on aluminum alloy against corrosion. Due to well-formed platelet LDH structure, nitrate ions properly intercalate between the interlayers and cause an increase in the chloride uptake and holding capacity, thus leading to the stabilization of the layered structure which prevents chloride ions migration to the underlying metal. That made LDH structures a compact system for entrapping the chloride ions and prevents the aggressive media from interacting with the aluminum surface.

Table 4. Evolution with a time of the fitting parameters $R_{\mathrm{LDH}}, Q_{\mathrm{LDH}}, \alpha_{\mathrm{LDH}}, R_{\mathrm{ct}}, Q_{\mathrm{dl}}$, and $\alpha_{\mathrm{dl}}$.

\begin{tabular}{|c|c|c|c|c|c|c|c|}
\hline Sample & $\begin{array}{c}\text { Immersion } \\
\text { Time }\end{array}$ & $\begin{array}{c}R_{\mathrm{LDH}} \\
\mathrm{k} \Omega \mathrm{cm}^{2}\end{array}$ & $\underset{\Omega^{-1} \mathrm{~cm}^{-2} \mathrm{~s}^{\alpha}}{Q_{\mathrm{LDH}}}$ & $\alpha_{\mathrm{LDH}}$ & $\begin{array}{c}R_{\mathrm{ct}} \\
\mathrm{k} \Omega \mathrm{cm}^{2}\end{array}$ & $\Omega^{-1} \stackrel{Q_{\mathrm{dl}}}{\mathrm{cm}^{-2} \mathrm{~s}^{\alpha}}$ & $\alpha_{\mathrm{dl}}$ \\
\hline NiAl-LDH & 1 day & 11.77 & $1.69 \times 10^{-6}$ & 0.91 & 308 & $1.41 \times 10^{-6}$ & 0.90 \\
\hline $\mathrm{NiAl}-\mathrm{LDH}_{\mathrm{b}}$ & 1 day & 21.87 & $7.62 \times 10^{-6}$ & 0.83 & 467 & $2.04 \times 10^{-6}$ & 0.90 \\
\hline $\mathrm{NiAl}-\mathrm{LDH}_{\mathrm{C}}$ & 1 day & 333.61 & $4.92 \times 10^{-7}$ & 0.51 & 1391 & $8.60 \times 10^{-7}$ & 0.70 \\
\hline NiAl-LDH ${ }_{d}$ & 1 day & 1208.8 & $5.78 \times 10^{-7}$ & 0.67 & 1819 & $4.19 \times 10^{-6}$ & 0.79 \\
\hline
\end{tabular}

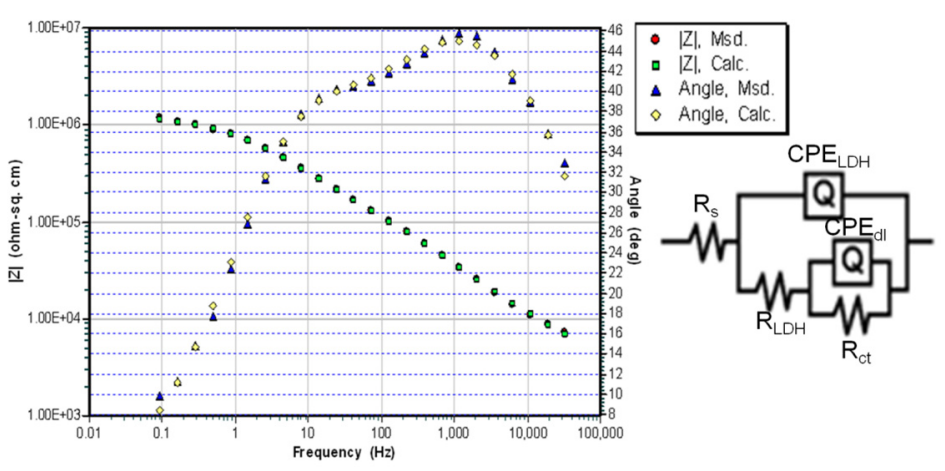

Figure 7. An example of electrochemical impedance spectroscopy (EIS) fitting of NiAl-LDH $\mathrm{L}_{\mathrm{d}}$ experimental data, and the equivalent circuit used to model the experimental results.

In Table 5 a comparison of the fitting parameters $R_{\mathrm{LDH}}$ and $R_{\mathrm{ct}}$ after 1 day of immersion in a sodium chloride electrolyte is reported. The value of $R_{\mathrm{LDH}}$ for the coatings developed in this study is remarkably higher compared to the data reported in the literature. However, one should consider that: 
(1) in this study the crystallization treatment has been prolonged in order to obtain relatively thick coatings, while in the literature very often only thin conversion layer of LDHs are investigated; (2) the electrolyte employed in this study is more diluted than $3.5 \mathrm{wt} \% \mathrm{NaCl}(0.1 \mathrm{M} \approx 0.58 \mathrm{wt} \%)$ : for this reason, higher resistance values are expected.

Table 5. Comparison with literature data referred to LDH thin films on aluminum alloys.

\begin{tabular}{cccccc}
\hline LDH & NaCl Conc. & Time & $\boldsymbol{R}_{\mathbf{L D H}} \mathbf{( \mathbf { k } \Omega \mathbf { ~ c m } ^ { \mathbf { 2 } } )}$ & $\boldsymbol{R}_{\mathbf{c t}}\left(\mathbf{k} \boldsymbol{\Omega} \mathbf{~ c m}^{\mathbf{2}}\right)$ & Ref. \\
\hline $\mathrm{Li} / \mathrm{Al}$ & $3.5 \mathrm{wt} \%$ & $0 \mathrm{~h}$ & 2.2 & 6490 & {$[35]$} \\
$\mathrm{Mg} / \mathrm{Al}$ & $3.5 \mathrm{wt} \%$ & 1 day & n.p. & 5.88 & {$[36]$} \\
$\mathrm{Li} / \mathrm{Al}$ & $3.5 \mathrm{wt} \%$ & 1 day & 0.8 & $0.18 \times 10^{3}$ & {$[37]$} \\
$\mathrm{Zn} / \mathrm{Al}\left(+\mathrm{VO}_{x}\right)$ & $0.05 \mathrm{M}$ & 1 day & 18.2 & $7.96 \times 10^{8}$ & {$[38]$} \\
$\mathrm{NiAl}-\mathrm{LDH}$ & $0.1 \mathrm{M}$ & 1 day & 1415 & 1819.9 & This work \\
\hline
\end{tabular}

To understand the Chloride entrapment capabilities of NiAl-LDHs, a direct Mohar chloride measurement method is used to measure chlorine adsorption behavior of LDHs before and after the contact with $0.1 \mathrm{M}$ chlorine solution for a period of one day. Here, silver nitrate is used as a reagent and potassium chromate as an indicator [39], the silver nitrate solution was added slowly in the tested chloride solution, and result the formation of a precipitate of silver chloride, while the endpoint of the titration occurs when all the chloride ions are precipitated and the addition of silver nitrate reacts with the chromate ions (indicator) to form a red-brown precipitate of silver chromate (Figure 8). The calculated concentration of chloride after contact with NiAl-LDH and for comparison the chlorine concentration in $0.1 \mathrm{M} \mathrm{NaCl}$ solution is listed in Table 6. It can be seen that the chloride uptake value for NiAl-LDH $\mathrm{L}_{\mathrm{d}}$ is much greater than the other prepared NiAl-LDHs. The mechanisms behind the chloride removal from the solution are likely to rely on the ion-exchange capability of the LDHs. In fact, the reduced amount of $\mathrm{Cl}^{-}$measured upon exposure to the NiAl-LDH is in agreement with the anions uptake in the film. Among the investigated samples, NiAl- $\mathrm{LDH}_{\mathrm{d}}$ has been found to combine the best corrosion protection properties (as suggested by polarization curves and EIS) as well as the highest chloride uptake capability. A hypothesis to explain these findings is to assume that chloride ions are entrapped inside the LDH structure (thanks to anions exchange mechanism), thus reducing the aggressiveness of the salt solution towards the metal substrate. Together with higher thickness, this would help to increase the corrosion protection properties of the LDH coating. Figure 9 shown the optical images of NiAl-LDHs after corrosion analysis and can be seen that LDH film remains visually intact and uniform, which is in agreement with the observed system stability of the LDHs.

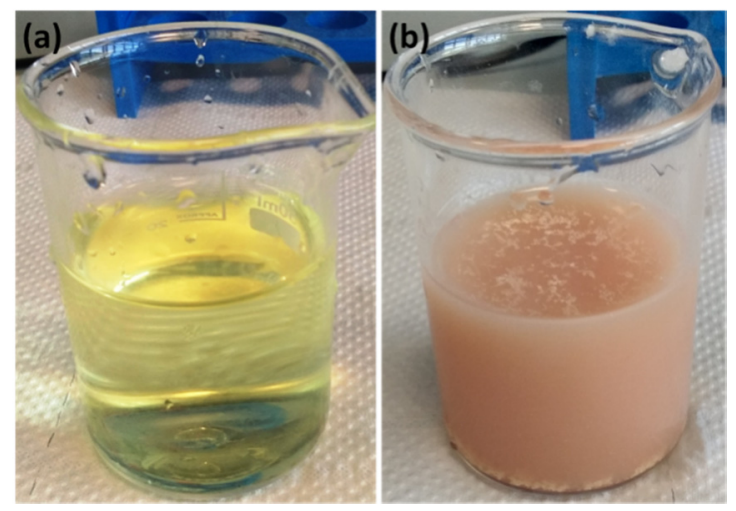

Figure 8. (a) The chromate indicator gives a faint lemon-yellow color of fresh $0.1 \mathrm{M} \mathrm{NaCl}$ solution. (b) The endpoint, all the $\mathrm{Cl}^{-}$ions have precipitated and with silver nitrate, precipitates with the chromate indicator giving a slight red-brown coloration. 
Table 6. The concentration of chloride in $0.1 \mathrm{M} \mathrm{NaCl}$ solution before and after contact with NiAl-LDHs after one-day immersion.

\begin{tabular}{|c|c|c|c|c|c|}
\hline & $\begin{array}{c}0.1 \mathrm{M} \mathrm{NaCl} \text { (Fresh) } \\
\mathrm{mg} \cdot \mathrm{L}^{-1}\end{array}$ & $\begin{array}{l}\mathrm{NiAl}-\mathrm{LDH}_{\mathrm{a}} \\
\mathrm{mg} \cdot \mathrm{L}^{-1}\end{array}$ & $\begin{array}{l}\mathrm{NiAl}-\mathrm{LDH}_{\mathrm{b}} \\
\mathrm{mg} \cdot \mathrm{L}^{-1}\end{array}$ & $\begin{array}{c}\mathrm{NiAl}-\mathrm{LDH}_{\mathrm{c}} \\
\mathrm{mg} \cdot \mathrm{L}^{-1}\end{array}$ & $\begin{array}{c}\mathrm{NiAl}-\mathrm{LDH}_{\mathrm{d}} \\
\mathrm{mg} \cdot \mathrm{L}^{-1}\end{array}$ \\
\hline Chloride Conc. & 3462 & 3426 & 3388 & 3340 & 3337 \\
\hline
\end{tabular}
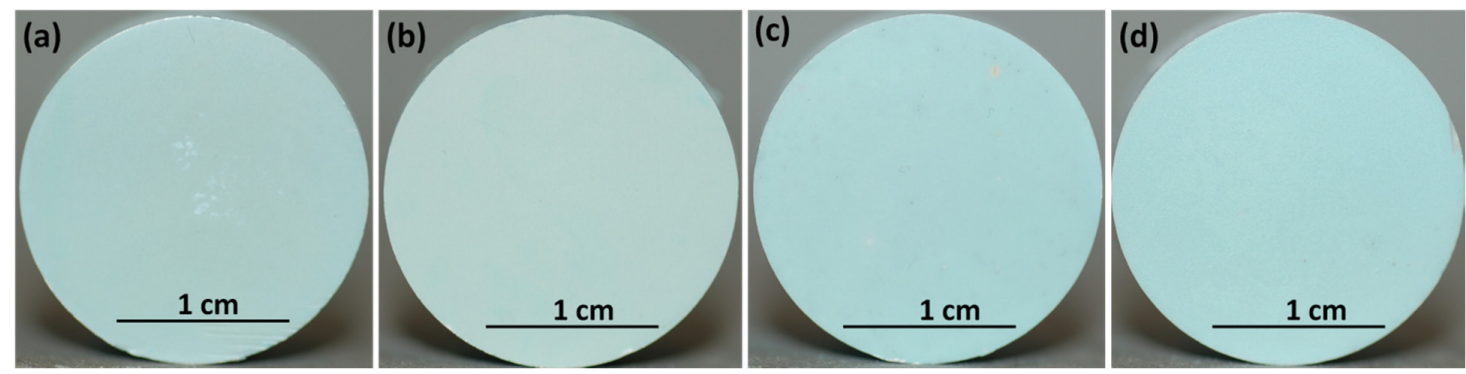

Figure 9. Specimen surfaces after corrosion test: (a) $\mathrm{NiAl}-\mathrm{LDH}_{\mathrm{a}}$, (b) NiAl-LDH $\mathrm{L}_{\mathrm{b}}$ (c) NiAl-LDH , (d) NiAl-LDH .

\section{Conclusions}

In this study, an in situ growth approach was used to prepare anticorrosive NiAl-LDHs of various morphologies on aluminum AA6082 substrate and the effect of different LDH surface morphologies on their ion exchange capability with $\mathrm{Cl}^{-}$and corresponding corrosion resistance properties are reported. It is revealed that platelet $\mathrm{NiAl}-\mathrm{LDH}_{\mathrm{d}}$ structure has shown better ion-uptake behavior compared to other analyzed morphologies. About $122 \mathrm{mg} / \mathrm{L}$ chloride uptake was observed from $0.1 \mathrm{M} \mathrm{NaCl}$ the electrolyte. In addition, it was found to remarkably reduce both the anodic and cathodic current compared to the bare substrate. The findings from EIS analysis furtherly confirmed the ability of $\mathrm{NiAl}-\mathrm{LDH}_{\mathrm{d}}$ to protect the underlying metal against corrosion.

Together with a physical barrier effect, the capability of the developed LDH structure to entrapped chloride ions, thus reducing the aggressiveness of the salt solution towards the metal substrate, are believed to be responsible for the observed increase in the corrosion protection properties of the LDH coating. As a general conclusion, the selection of an appropriate choice of metal cations ratio and microstructure optimization seems to play a key role in the development of LDH coatings with enhanced corrosion protection properties.

Author Contributions: Conceptualization, M.F. and M.A.I.; methodology, M.A.I. and M.F.; software, M.A.I.; validation, L.S. and M.F.; formal analysis, M.A.I., M.F. and H.A.; investigation resources, M.F., H.A. and L.S.; data curation, M.A.I. and H.A.; writing — original draft preparation, M.A.I.; writing — review and editing, M.F. and L.S.; visualization, M.F.; supervision, L.S. and M.F. All authors have read and agreed to the published version of the manuscript.

Funding: This research received no external funding.

Conflicts of Interest: The authors declare no conflict of interest.

\section{References}

1. Schäfer, H.; Stock, H.-R. Improving the corrosion protection of aluminium alloys using reactive magnetron sputtering. Corros. Sci. 2005, 47, 953-964. [CrossRef]

2. Venugopal, A.; Panda, R.; Manwatkar, S.; Sreekumar, K.; Krishna, L.R.; Sundararajan, G. Effect of micro arc oxidation treatment on localized corrosion behaviour of AA7075 aluminum alloy in $3.5 \% \mathrm{NaCl}$ solution. Trans. Nonferrous Met. Soc. China 2012, 22, 700-710. [CrossRef]

3. Qu, J.-E.; Chen, G.; Wang, H.; Nie, D.-J. Effect of water content on corrosion inhibition behavior of self-assembled TDPA on aluminum alloy surface. Trans. Nonferrous Met. Soc. China 2013, 23, 3137-3144. [CrossRef] 
4. Lutz, A.; Berg, O.V.D.; Van Damme, J.; Verheyen, K.; Bauters, E.; De Graeve, I.; Du Prez, F.E.; Terryn, H. A Shape-Recovery Polymer Coating for the Corrosion Protection of Metallic Surfaces. ACS Appl. Mater. Interfaces 2014, 7, 175-183. [CrossRef] [PubMed]

5. Shi, H.; Han, E.-H.; Liu, F.; Kallip, S. Protection of 2024-T3 aluminium alloy by corrosion resistant phytic acid conversion coating. Appl. Surf. Sci. 2013, 280, 325-331. [CrossRef]

6. Guo, X.; Zhang, F.; Peng, Q.; Xu, S.; Lei, X.; Evans, D.G.; Duan, X. Layered double hydroxide/eggshell membrane: An inorganic biocomposite membrane as an efficient adsorbent for $\mathrm{Cr}(\mathrm{VI})$ removal. Chem. Eng. J. 2011, 166, 81-87. [CrossRef]

7. Yang, J.-H.; Han, Y.-S.; Park, M.; Park, T.; Hwang, S.-J.; Choy, J.-H. New Inorganic-Based Drug Delivery System of Indole-3-Acetic Acid-Layered Metal Hydroxide Nanohybrids with Controlled Release Rate. Chem. Mater. 2007, 19, 2679-2685. [CrossRef]

8. Iqbal, M.A.; Asghar, H.; Iqbal, M.A.; Fedel, M. Sorption of As(V) from aqueous solution using in situ growth $\mathrm{MgAl}-\mathrm{NO}_{3}$ layered double hydroxide thin film developed on AA6082. SN Appl. Sci. 2019, 1, 666. [CrossRef]

9. Ladewig, K.; Xu, Z.P.; Lu, G. (Max) Layered double hydroxide nanoparticles in gene and drug delivery. Expert Opin. Drug Deliv. 2009, 6, 907-922. [CrossRef]

10. Iqbal, M.A.; Fedel, M. Effect of Synthesis Conditions on the Controlled Growth of MgAl-LDH Corrosion Resistance Film: Structure and Corrosion Resistance Properties. Coatings 2019, 9, 30. [CrossRef]

11. Iqbal, M.A.; Sun, L.; LaChance, A.M.; Ding, H.; Fedel, M. In situ growth of a CaAl-NO 3--layered double hydroxide film directly on an aluminum alloy for corrosion resistance. Dalton Trans. 2020, 49, 3956-3964. [CrossRef] [PubMed]

12. Iqbal, M.A.; Fedel, M. The effect of the surface morphologies on the corrosion resistance of in situ growth MgAl-LDH based conversion film on AA6082. Surf. Coat. Technol. 2018, 352, 166-174. [CrossRef]

13. Iqbal, M.A.; Fedel, M. Effect of operating parameters on the structural growth of ZnAl layered double hydroxide on AA6082 and corresponding corrosion resistance properties. J. Coat. Technol. Res. 2019, 16, 1423-1433. [CrossRef]

14. Sun, X.; Neuperger, E.; Dey, S. Insights into the synthesis of layered double hydroxide (LDH) nanoparticles: Part 1. Optimization and controlled synthesis of chloride-intercalated LDH. J. Colloid Interface Sci. 2015, 459, 264-272. [CrossRef]

15. Israëli, Y.; Taviot-Gueho, C.; Besse, J.-P.; Morel, J.-P.; Morel-Desrosiers, N. Thermodynamics of anion exchange on a chloride-intercalated zinc-aluminum layered double hydroxide: A microcalorimetric study. J. Chem. Soc. Dalton Trans. 2000, 791-796. [CrossRef]

16. Cao, Y.; Zheng, D.; Li, X.; Lin, J.; Wang, C.; Dong, S.; Lin, C. Enhanced Corrosion Resistance of Superhydrophobic Layered Double Hydroxide Films with Long-Term Stability on Al Substrate. ACS Appl. Mater. Interfaces 2018, 10, 15150-15162. [CrossRef]

17. Lv, Z.; Yang, S.; Zhu, H.; Chen, L.; Alharbi, N.; Wakeel, M.; Wahid, A.; Chen, C. Highly efficient removal of As(V) by using NiAl layered double oxide composites. Appl. Surf. Sci. 2018, 448, 599-608. [CrossRef]

18. Ye, X.; Jiang, Z.; Li, L.; Xie, Z. In-Situ Growth of NiAl-Layered Double Hydroxide on AZ31 Mg Alloy towards Enhanced Corrosion Protection. Nanomaterials 2018, 8, 411. [CrossRef]

19. Zhang, F.; Guo, L.; Xu, S.; Zhang, R. Preparation of Nickel-Aluminum-Containing Layered Double Hydroxide Films by Secondary (Seeded) Growth Method and Their Electrochemical Properties. Langmuir 2015, 31, 6704-6712. [CrossRef]

20. Liu, Y.; Yu, T.; Cai, R.; Li, Y.; Yang, W.; Caro, J. One-pot synthesis of NiAl-CO3 LDH anti-corrosion coatings from CO2-saturated precursors. RSC Adv. 2015, 5, 29552-29557. [CrossRef]

21. Chen, H.; Zhang, F.; Fu, S.; Duan, X. In Situ Microstructure Control of Oriented Layered Double Hydroxide Monolayer Films with Curved Hexagonal Crystals as Superhydrophobic Materials. Adv. Mater. 2006, 18, 3089-3093. [CrossRef]

22. Abderrazek, K.; Srasra, N.F.; Srasra, E. Synthesis and Characterization of [Zn-Al] Layered Double Hydroxides: Effect of the Operating Parameters. J. Chin. Chem. Soc. 2017, 64, 346-353. [CrossRef]

23. Kameda, T.; Fubasami, Y.; Yoshioka, T. Kinetics and equilibrium studies on the treatment of nitric acid with $\mathrm{Mg}-\mathrm{Al}$ oxide obtained by thermal decomposition of NO3-intercalated $\mathrm{Mg}-\mathrm{Al}$ layered double hydroxide. J. Colloid Interface Sci. 2011, 362, 497-502. [CrossRef] [PubMed] 
24. Iqbal, M.A.; Fedel, M. Ordering and disordering of in situ grown MgAl-layered double hydroxide and its effect on the structural and corrosion resistance properties. Int. J. Miner. Met. Mater. 2019, 26, 1570-1577. [CrossRef]

25. Aisawa, S.; Hirahara, H.; Uchiyama, H.; Takahashi, S.; Narita, E. Synthesis and Thermal Decomposition of Mn-Al Layered Double Hydroxides. J. Solid State Chem. 2002, 167, 152-159. [CrossRef]

26. Wu, Q.; Olafsen, A.; Ørnulv, V.; Roots, J.; Norby, P. Delamination and restacking of a layered double hydroxide with nitrate as counter anion. J. Mater. Chem. 2005, 15, 4695. [CrossRef]

27. Kloprogge, T.; Frost, R.L. Fourier Transform Infrared and Raman Spectroscopic Study of the Local Structure of Mg-, Ni-, and Co-Hydrotalcites. J. Solid State Chem. 1999, 146, 506-515. [CrossRef]

28. Bukhtiyarova, M.V. A review on effect of synthesis conditions on the formation of layered double hydroxides. J. Solid State Chem. 2019, 269, 494-506. [CrossRef]

29. Mikhailau, A.; Maltanava, H.; Poznyak, S.K.; Salak, A.N.; Zheludkevich, M.L.; Yasakau, K.; Ferreira, M. One-step synthesis and growth mechanism of nitrate intercalated $\mathrm{ZnAl} \mathrm{LDH}$ conversion coatings on zinc. Chem. Commun. 2019, 55, 6878-6881. [CrossRef]

30. Chen, J.; Song, Y.; Shan, D.; Han, E.-H. In situ growth of Mg-Al hydrotalcite conversion film on AZ31 magnesium alloy. Corros. Sci. 2011, 53, 3281-3288. [CrossRef]

31. Serdechnova, M.; Mohedano, M.; Kuznetsov, B.; Mendis, C.L.; Starykevich, M.; Karpushenkov, S.; Tedim, J.; Ferreira, M.; Blawert, C.; Zheludkevich, M. PEO Coatings with Active Protection Based on In-Situ Formed LDH-Nanocontainers. J. Electrochem. Soc. 2016, 164, C36-C45. [CrossRef]

32. Oestreicher, V.; Fábregas, I.; Jobbagy, M. One-Pot Epoxide-Driven Synthesis of M2Al(OH)6Cl-1.5H2O Layered Double Hydroxides: Precipitation Mechanism and Relative Stabilities. J. Phys. Chem. C 2014, 118, 30274-30281. [CrossRef]

33. Chen, J.; Song, Y.; Shan, D.; Han, E.-H. Modifications of the hydrotalcite film on AZ31 Mg alloy by phytic acid: The effects on morphology, composition and corrosion resistance. Corros. Sci. 2013, 74, 130-138. [CrossRef]

34. Tedim, J.; Kuznetsova, A.; Salak, A.N.; Montemor, F.; Snihirova, D.; Pilz, M.; Zheludkevich, M.; Ferreira, M. $\mathrm{Zn}-\mathrm{Al}$ layered double hydroxides as chloride nanotraps in active protective coatings. Corros. Sci. 2012, 55, 1-4. [CrossRef]

35. Zhang, C.; Luo, X.; Pan, X.; Liao, L.; Wu, X.; Liu, Y. Self-healing Li-Al layered double hydroxide conversion coating modified with aspartic acid for 6N01 Al alloy. Appl. Surf. Sci. 2017, 394, 275-281. [CrossRef]

36. Wang, F.; Guo, Z. Insitu growth of durable superhydrophobic Mg-Al layered double hydroxides nanoplatelets on aluminum alloys for corrosion resistance. J. Alloys Compd. 2018, 767, 382-391. [CrossRef]

37. Lin, K.; Luo, X.; Pan, X.; Zhang, C.; Liu, Y. Enhanced corrosion resistance of LiAl-layered double hydroxide $(\mathrm{LDH})$ coating modified with a Schiff base salt on aluminum alloy by one step in-situ synthesis at low temperature. Appl. Surf. Sci. 2019, 463, 1085-1096. [CrossRef]

38. Tedim, J.; Zheludkevich, M.; Bastos, A.; Salak, A.N.; Lisenkov, A.; Ferreira, M. Influence of preparation conditions of Layered Double Hydroxide conversion films on corrosion protection. Electrochim. Acta 2014, 117, 164-171. [CrossRef]

39. Korkmaz, D. Precipitation titration: “Determination of Chloride by the Mohr Method". Methods 2001, 2, 1-6. 